\title{
Citronensaures Eisenoxyd.
}

Ma cquet in Namur giebt dazu folgende Vorschrift: Reine trockne Citronensäure wird in einer Porcellanschale bei Sandbadwärme mit $8-9$ Theilen frischbereitetem, gallertartigem Eisenoxydhydrat neutralisirt, die dünnflüssige Masse filtrirt und in sebr dünnen Schichten auf mit Papier überdeckten Tellern der Verdunstung überlassen. Nach Verlauf einiger Tage löst sich das Präparat in glänzenden, durchsichıgen, granatrothen, leicht und völlig löslichen Schuppen ab. (Journ. de Pharm. d'Anvers I. - Jahrb. f. d. Pharm. XI. Bd. p. 432.) B.

\section{Destillation des baldriansauren Baryts.}

Chancel unterwarf baldriansauren Baryt, der mit einer direct aus Baldrian gewonnenen Säure bereitet war und sich als völlig rein erwies, der trocknen Destillation. Er verliert bei $+350^{\circ}$ sein Krystallwasser und fängt erst stärker erhitzt an sich zu zersetzen, wobei ein brennbares Gas entwickelt wird und einige Tröpfchen einer stark riechenden Flüssigkeit übergehen. Erst in Rothgluhbitze erfolgt die völlige Zersetzung. Der Rückstand isı kohlensaurer Baryt, verunreinigt mit Kohle. Das Destillat wurde mehrmals rectificirt, wonach es dann klar und farblos und sehr beweglich war. Der Verfasser nennt es Valeral oder Valerianaldehyd. Es hat einen brennenden Geschmack und durchdringenden Geruch, ist in allen Verhältnissen in Alkohol, Aether und ätherischen Oelen löslich, siedet bei etwa $+110^{\circ}$ und hat 0,820 spec. Gew. bei $+22^{\circ}$. Das Valeral brennt leicht mit glänzender Flamme. Oxydirende Körper verwandeln es in Valerianasäure. Salzsäure verbindet sich mit ihm zu einer Flüssigkeit, welche dichter als Wasser und überhaupt der Buttersalpetersäure sehr ähnlich ist, wesshalb der Verfasser sie Valerianasalpetersäure nennt. Die Analyse des Valerals gab $\mathrm{C}^{10} \mathrm{H}^{10} \mathrm{O}^{2}$, was in procentischer Zusammensetzung $=69,8$ Kohlenstoff, 11,6 Wasserstoff, 18,6 Sauerstoff ist. Das gefundene Gewicht des Dampfes war 2,93, das berechnete ist 2,96. (Compl. rend. XXI.-Pharm. Centrbl. Nr. 8. 1846.) B.

\section{Verfahren um den Blutegeln das Blut zu entziehen.}

Boyce empfiehlt zu diesem Zwecke als das beste Mittel die Mixtura Camphorae Pharm. Londin, eine wäs- 